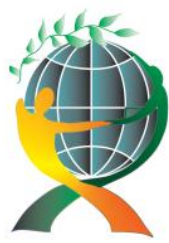

\author{
(online) $=$ ISSN $2285-3642$ \\ ISSN-L = 2285 - 3642 \\ Journal of Economic Development, Environment and People \\ Volume 3, Issue 2, 2014
}

URL: http://jedep.spiruharet.ro

e-mail: office jedep@spiruharet.ro

\title{
Empirical Investigation of Industrial Management
}

\author{
Professor Elenko Zahariev, PhD \\ University of Agribusiness and Rural Development - Plovdiv, Bulgaria \\ ezahariev@uard.bg
}

\begin{abstract}
The paper is devoted to an aspect in the sphere of management - business priorities of industrial management in XXI century. In modern times the actuality of treated problems is mainly laid into the necessities of the real management practice in industrial organizations and the need theoretical and applied knowledge to be offered to that practice which would allow it methodologically right and methodically correct to implement the corresponding changes in management of a concrete organization. Objects of analyses and evaluations are some fragmented approbations of theses using the corresponding instruments. The characteristic features of the organizations' profiles and the persons interviewed participated in the investigation are summarized. The determining approaches for Bulgarian organizations are considered too.

On the basis of the critical analyses the fundamental tasks are drawn which are inherent to contemporary industrial managers. Attention is paid to key management functions for an effective managerial process. An analysis of managers reaching the best results in industrial management is presented as well as when they are reached. Outlined are also specific peculiarities of industrial management in the Republic of Bulgaria and parameters of the level of productiveness in conditions of business globalization and priority forms in marketing of the ready product / service in XXI century. The results of the launched idea for the necessity to create a new International management architecture (NIMA) are determined - structure and structure defining parameters. The results of the investigation of main business priorities in industrial management are commented as well as expected problems in the process of functioning of industrial organizations in XXI century. At the end the corresponding conclusions are made in respect to the techniques used in determining effectiveness of industrial management in Bulgarian organizations.
\end{abstract}

Keywords: industrial management, management architectonics, respondents, business priorities, globalization, global environment, management architecture, management approaches, fundamental management tasks, key management functions, economic effectiveness, financial profitableness, growth analysis

JEL Codes: G32, F6, F64

\section{Introduction}

Development, introduction and exploitation of organizational innovations in management are continuous, cyclically repeated processes implemented by man but subordinating to definite objective regularities finally. Their acquaintance and use in the economical practice is a necessary condition for the progress of industrial management. The purpose of the paper is to determine at what extent is the availability of relationship between theoretical and methodological fundamentals of industrial 


\author{
(online) $=$ ISSN $2285-3642$ \\ ISSN-L = 2285-3642 \\ Journal of Economic Development, Environment and People \\ Volume 3, Issue 2, 2014 \\ URL: $\underline{\text { http://jedep.spiruharet.ro }}$ \\ e-mail: office jedep@spiruharet.ro
}

management and its state in Bulgaria on the basis of a study of the practical experience in that field ${ }^{1}$. The study considers expected business priorities of industrial management in the country during XXI century and the necessity to create a new form - the New International Management Architecture (NIMA), for distribution and popularization of good management practices in industrial management which to be accompanied by a strong regulation and achieved consensus in creation and introduction of alternative forms of institutionalization of professional standards, control and monitoring over industrial management.

The industrial companies should take in account ISO 9001 Quality Management System (QMS). In his paper [Oliveira, 2013] the author proposed guidelines that were divided into three phases: a) integration planning, b) integration development, and c) integration control and improvement.

The marketing managers in industrial companies have to make progress in attaining theoretical unity in understanding of buyer-seller relationships and industrial networks. [Peters, 2013]

The objects of investigation are industrial managers and specialists in organizations with different structure of ownership, reflecting the essence and the content, laws and regularities in industrial management. The choice is substantiated by the following considerations: First, contemporary industrial managers, besides approaches towards management and key management functions, face three fundamental management tasks: activities and organization management, human resources management, production and operations management - and the prosperity of economy and society as a whole is dependent on their successful implementation. Second, the dynamics in the structure of industrial managers and specialists, strict conformity to key parameters of companies' management and organizational restructuring in industrial organizations in direction of conformation to main business priorities of the Republic of Bulgaria in XXI century pose problems which solution sets the necessity of effective industrial management.

The main reason for the lack in new facilities managers is the severely limited number of formal academic programs that specifically educate students in FM. [Meneghetti, 2012]

\title{
2. Material and methods
}

\subsection{Parameters of investigation}

The investigation is conducted in the period September 2009 - June 2010 with representatives of economic subjects on the territory of the Republic of Bulgaria. On the basis of the prepared sample are conducted 106 effective interviews with managers and specialists from different hierarchical levels in different branches, sub-branches and production types. The method of information collection is a direct standardized interview. The information is manipulated using statistical software product SPSS. Specialized

\footnotetext{
${ }^{1}$ The current study is a result of a self-dependent investigation of the author. The priorities of new realities in development of management theory and practice are deduced and the objective necessity of a new ideology for the priorities of the Republic of Bulgaria in XXI century are substantiated - entrepreneurship, industrial management in new global environment, knowledge-based economy, corporate social responsibility and ethics, new corporative culture, as well as the ways of application.
} 


\author{
(online) $=$ ISSN $2285-3642$ \\ ISSN-L = $2285-3642$ \\ Journal of Economic Development, Environment and People \\ Volume 3, Issue 2, 2014 \\ URL: http://jedep.spiruharet.ro \\ e-mail: office jedep@spiruharet.ro
}

instruments are developed for studying the state of industrial management in Bulgarian organizations in the type of a questionnaire form. It is used in the registration of the individual information and contains 25 questions put to persons under investigation. The questions are conditionally grouped in several thematic sub-groups:

1. Principal fundamentals of industrial management. The purpose is to reveal its architectonics including:

- main approaches - classical, behavioral and scientific;

- opportunities for their integration in contemporary conditions;

- fundamental management tasks connected to the management of activities and organization, human resources management and production and operations management;

- key management functions - planning, organization and control.

2. Results of application of industrial management and the dependence on:

- education;

- duration of executed functions;

- team work;

- key parameters of companies' activity;

- business internationalization;

- productivity and quality of work;

- priority forms in the marketing of the ready product / service.

3. Positioning of the main priorities in industrial management - they are drawn as:

- structure defining parameters of NIMA;

- management in globalizing world;

- social responsibility and ethics in the organization;

- entrepreneurship;

- career management.

4. Instruments for determining the effectiveness of industrial management - because of the lack of universal instruments several techniques are scrutinized:

- analysis of economic effectiveness of the organization;

- analysis of financial profitableness;

- analysis of the growth.

In the questionnaire the notional indicators are operationalized and verified from the point of view of the subsequent processing, analysis and interpretation of the collected results.

\title{
3. Results and discussion
}

\subsection{Profile of the organizations participated in the investigation}

According to the object of activity the economical subjects are grouped after answering spontaneously an open question. Five are the identified activities grouped according the Classification of economic 


\author{
(online) $=$ ISSN $2285-3642$ \\ ISSN-L = 2285 - 3642 \\ Journal of Economic Development, Environment and People \\ Volume 3, Issue 2, 2014 \\ URL: http://jedep.spiruharet.ro \\ e-mail: office jedep@spiruharet.ro
}

activities 2008. Three of them have approximately even weight in the investigation - processing industry (C $-25 \%)$, production and distribution of electric and heat energy and gas fuels (D - 24\%) and other activities (S-25\%). Almost $25 \%$ of the interviewees are representatives of trade, car and motorbike repair (G - $16 \%)$ and extractive industry (B - 10\%) (Fig. 1).

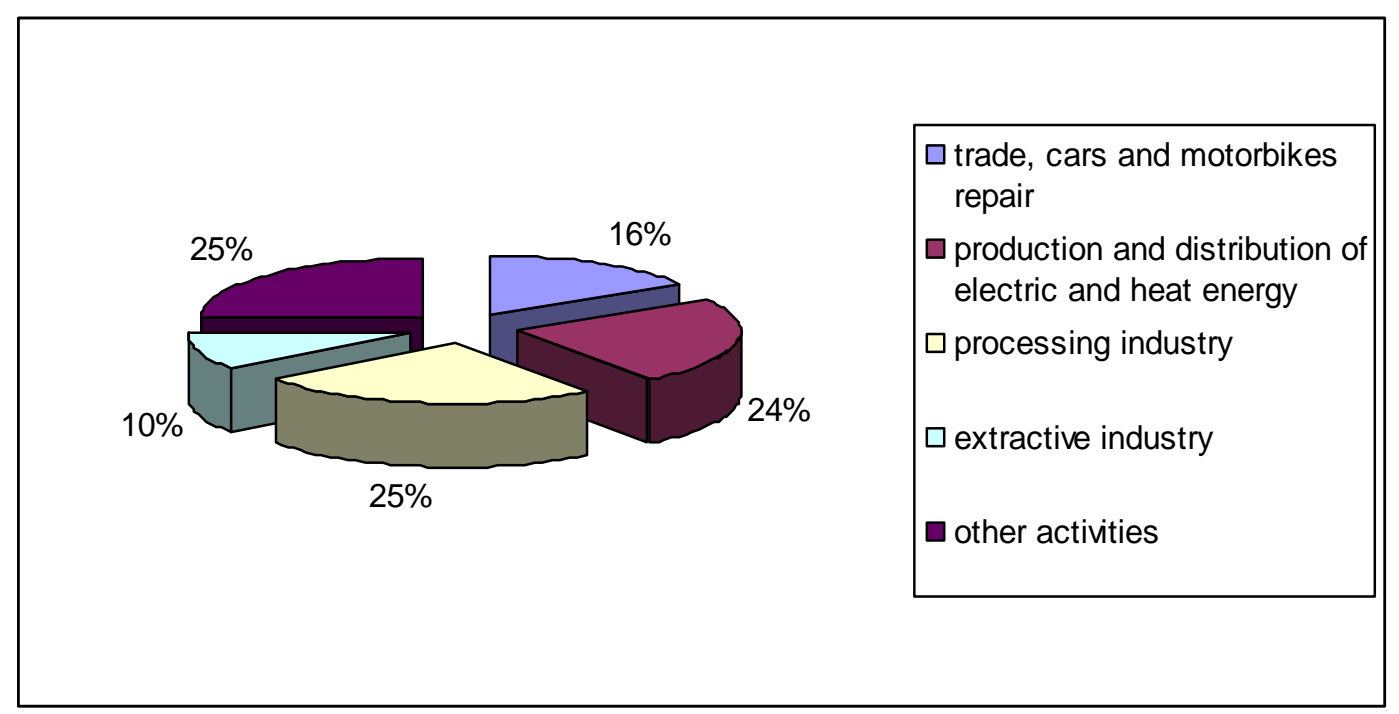

Fig. 1: The main objects of activity of the organizations took participation in the investigation

The share of the organizations with foreign partnership (partial or whole) in comparison to Bulgarian is in the relation 1:3. Mixed companies and those whose property is only to foreign investors are both equal numbers (13\% of the respondents) (Fig. 2). 

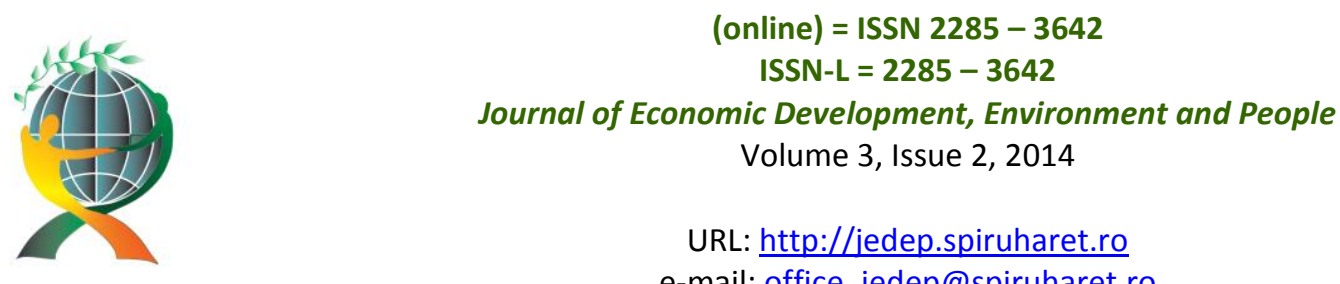

URL: $\underline{\text { http://jedep.spiruharet.ro }}$

e-mail: office jedep@spiruharet.ro

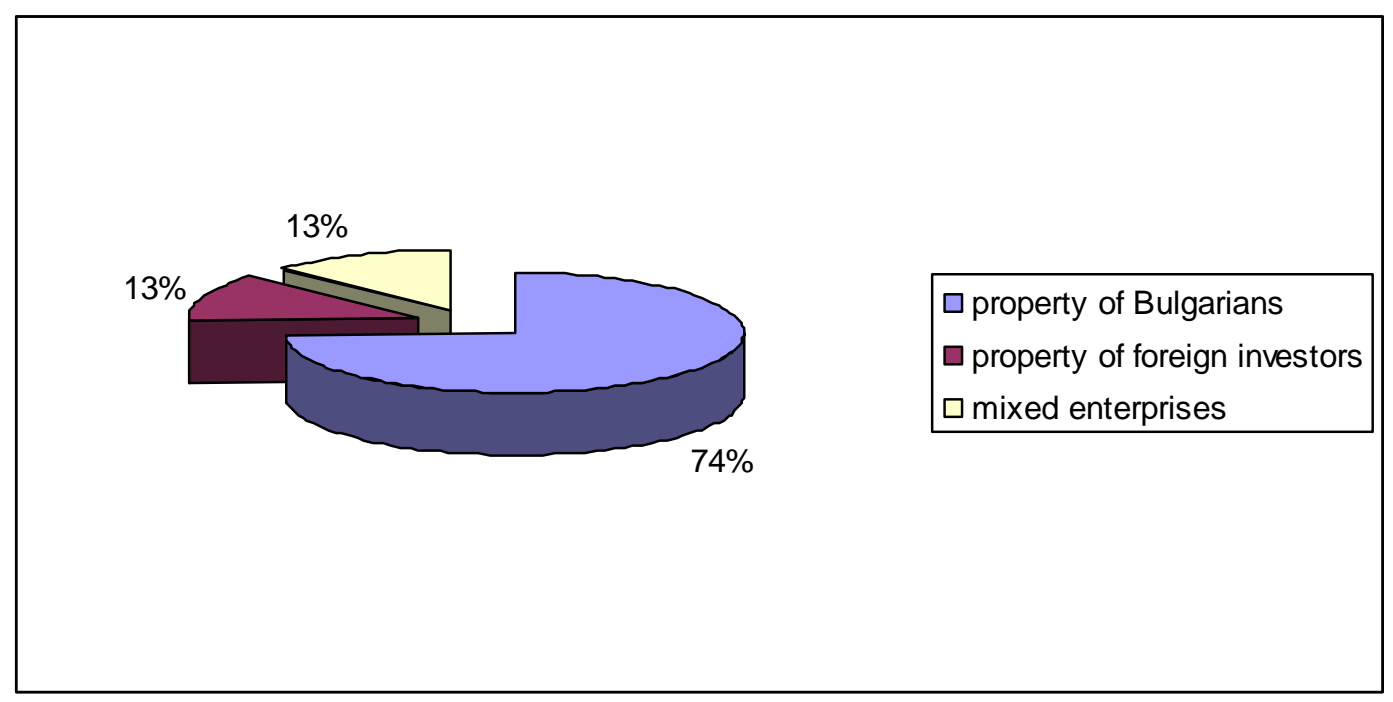

Fig. 2: Ownership of the interviewed organizations

From the point of view of juridical status, in the investigation a broad spectrum of organizations is embraced. The representatives of privately-owned joint-stock company and joint-stock company are $29 \%$ and $23 \%$ respectively. Privately-owned limited liability companies $-13 \%$, limited liability companies $-10 \%$. Holdings and sole proprietors are $9 \%$ and $6 \%$ respectively. Limited joint-stock companies are $1 \%$, and other $-9 \%$ of the interviewees.

The size of the organizations is determined by the number of their employees. In the investigation the groups of economical subjects with different employees' number are represented comparatively equal. The organizations with staff from 51 to 100 persons are $4 \%, 101-250-11 \%$, united in a group (Fig. 3). 
(online) = ISSN $2285-3642$

ISSN-L = $2285-3642$

Journal of Economic Development, Environment and People

Volume 3, Issue 2, 2014

URL: $\underline{\text { http://jedep.spiruharet.ro }}$

e-mail: office jedep@spiruharet.ro

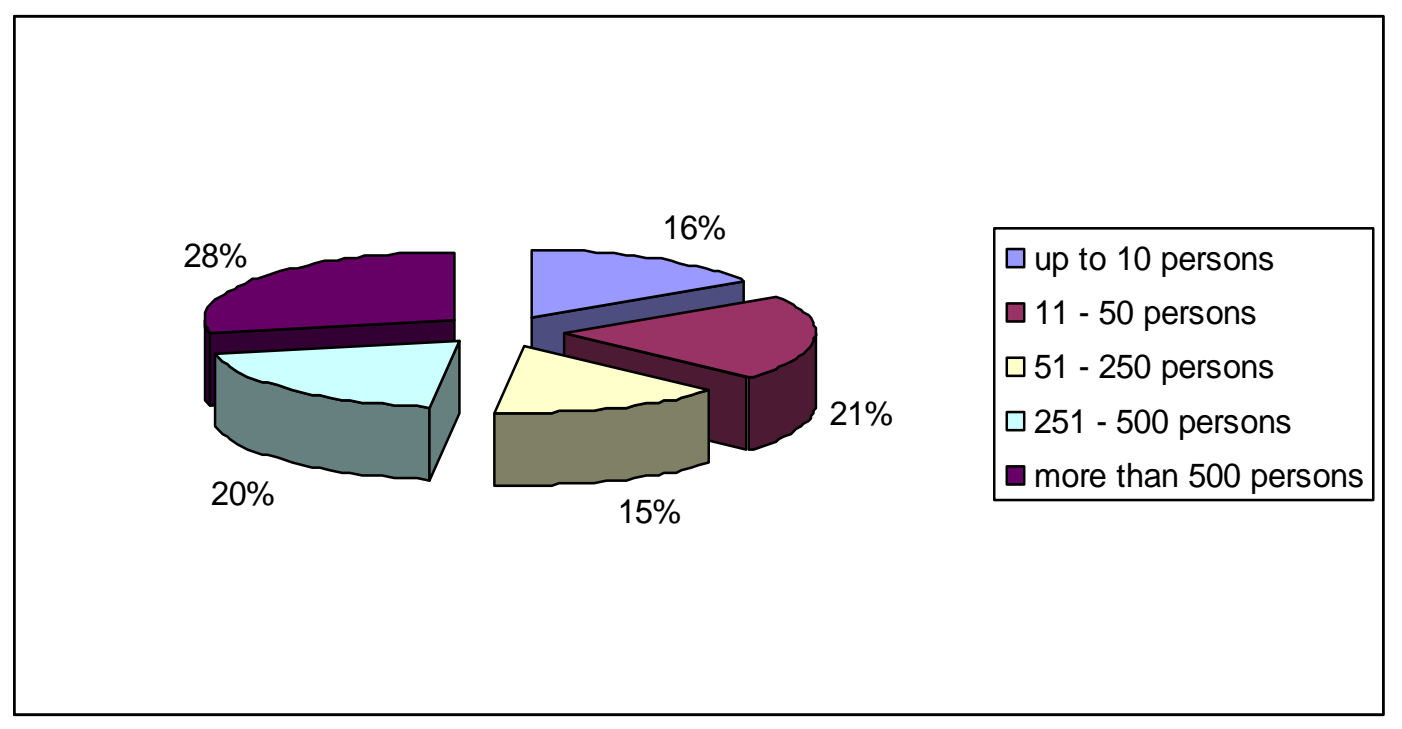

Fig. 3: The size of the organizations participated in the investigation

According to the management organizational structure, the economical subjects are grouped after answering an open question. The biggest number is that of functional organization management structure $-37 \%$, and linear $-30 \%$. Divisional $-14 \%$, linear-staff $-6 \%$. The percentage of those that had not answered is not small $-13 \%$.

\subsection{Profile of the interviewees}

Among the most important parameter for the needs of current investigation are occupations of the interviewees in the frameworks of organizational structures. The expert level of the posed questions requires participation of persons occupied on high levels in the organization's hierarchy. That's why over the half interviewees are high managers (58\%). Functional managers are $25 \%$, specialists $-17 \%$.

A direct connection with the occupation in the organization's hierarchy and the needed expertise level in the investigation has the degree of education of the interviewees. $84 \%$ of the interviewees have higher education. $83 \%$ point only higher education, $1 \%$ higher technical education. Both groups are united in the group of higher education graduates. High education graduates are another main group $-16 \%$ ( $8 \%$ high professional education, $6 \%$ only high education, $2 \%$ high economic education).

Regarding gender men have bigger participation in the investigation ( $71 \%$ of the interviewees), women $29 \%$.

Looking at the age (Fig. 4), good representation of all age groups could be reported: $31-40$ years (30\%) and $41-50$ years (29\%) are the main groups because of the required high level in the organization's hierarchy which are very active in respect to career development. 
(online) = ISSN $2285-3642$

ISSN-L = 2285 - 3642

Journal of Economic Development, Environment and People

Volume 3, Issue 2, 2014

URL: http://jedep.spiruharet.ro

e-mail: office jedep@spiruharet.ro

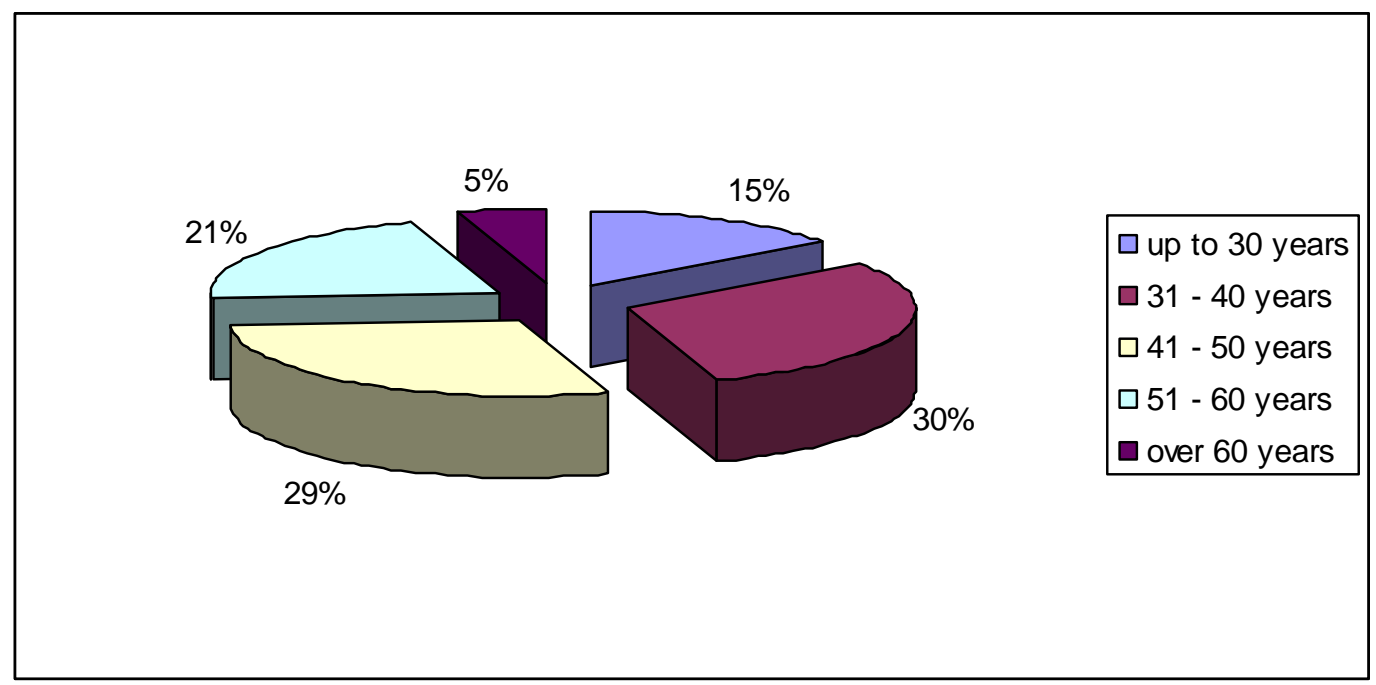

Fig. 4: Age distribution of the interviewees

\subsection{Main results of the investigation}

After processing filled questionnaires the following trends are pointed in respect to the problems under investigation:

\subsubsection{Industrial management in the Republic of Bulgaria}

On the question of determining for the organization approaches towards industrial management, $67 \%$ of the interviewees reply that it's the classical approach, mainly companies in extractive industry and processing industry (73\% each). Classical approach is determining for $70 \%$ of Bulgarian and for $69 \%$ of mixed companies. Regarding the professionals acknowledging that approach in their organizations, those are $80 \%$ of functional managers and $80 \%$ of the interviewees aged $51-60$. 


\author{
(online) $=$ ISSN $2285-3642$ \\ ISSN-L = $2285-3642$ \\ Journal of Economic Development, Environment and People \\ Volume 3, Issue 2, 2014 \\ URL: http://jedep.spiruharet.ro \\ e-mail: office jedep@spiruharet.ro
}

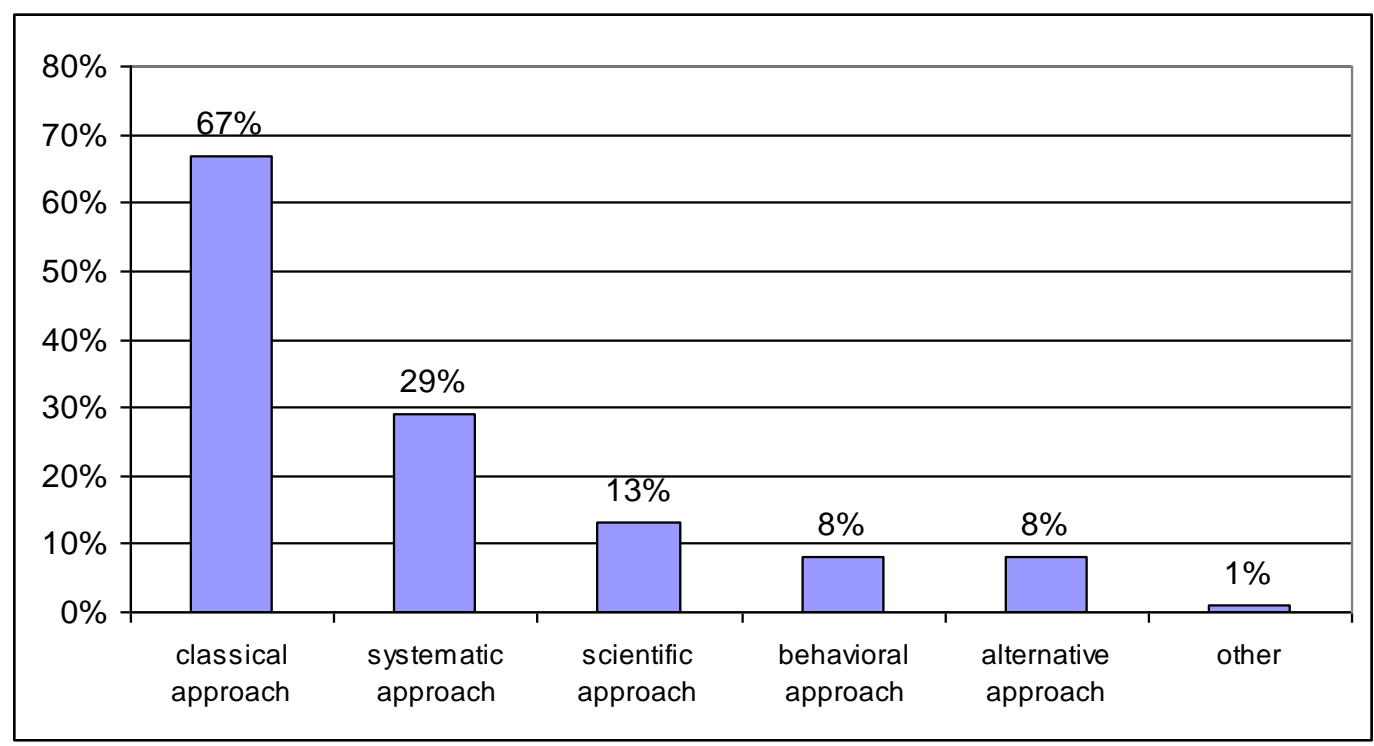

Fig. 5. Answers to the question "What approaches towards industrial management are appropriate for your organization" (more than one answer is possible)

The second position is for systematic approach which is pointed by $29 \%$ of the interviewees. It is the determining one for $55 \%$ of the companies in extractive industry and $44 \%$ of occupied in production and distribution of electric and heat energy and gas fuels. The systematic approach is the leading one for the half of small enterprises with staff from 11 to 50 , as well as for $36 \%$ of high managers.

The scientific approach is determining for $13 \%$. That is the approach of those organizations with the object of activity in trade, car and motorbike repair (for $29 \%$ of them), as well as for $23 \%$ of enterprises being property of foreign investors. For $20 \%$ of big economical subjects with staff over 500 persons, the scientific approach is the key one, as well as for $27 \%$ of the interviewees having high education. Behavioral and alternative approaches are leading only for $8 \%$ of the organizations each (Fig. 5).

In respect to managerial tasks, the most fundamental for $70 \%$ of the interviewees is the management of the activity of organization (Fig. 6). The biggest percentage adherents (91\%) that understand have among representatives of extractive industry. Reserved towards that topic are the representatives of small organizations (staff up to 10 persons) $-47 \%$, while for the rest support over $70 \%$ is reported. All representatives of linear-staff structure are behind the management of the activity of organization. High percentage is reported among the interviewees aged $51-60(90 \%)$ too, over 60 years $-100 \%$ share the thesis.

Another managerial task, which is supported by $47 \%$, is human resources management in organizations. It is essential for big organizations - supported by $58 \%$ of the representatives of the companies having staff over 251 persons. The representatives of divisional structure $(67 \%$ of them) and functional managers ( $52 \%$ of them) are among the biggest adherents to human resources management as a fundamental managerial task. 


\author{
(online) $=$ ISSN $2285-3642$ \\ ISSN-L = 2285 - 3642 \\ Journal of Economic Development, Environment and People \\ Volume 3, Issue 2, 2014 \\ URL: http://jedep.spiruharet.ro \\ e-mail: office jedep@spiruharet.ro
}

Production and operations management is pointed by $40 \%$ of the interviewees - companies having staff over $251 \%$ ( $54 \%$ of them point production and operations management), as well as $80 \%$ of the representatives of divisional structure - similarity in the profile with the preceding.

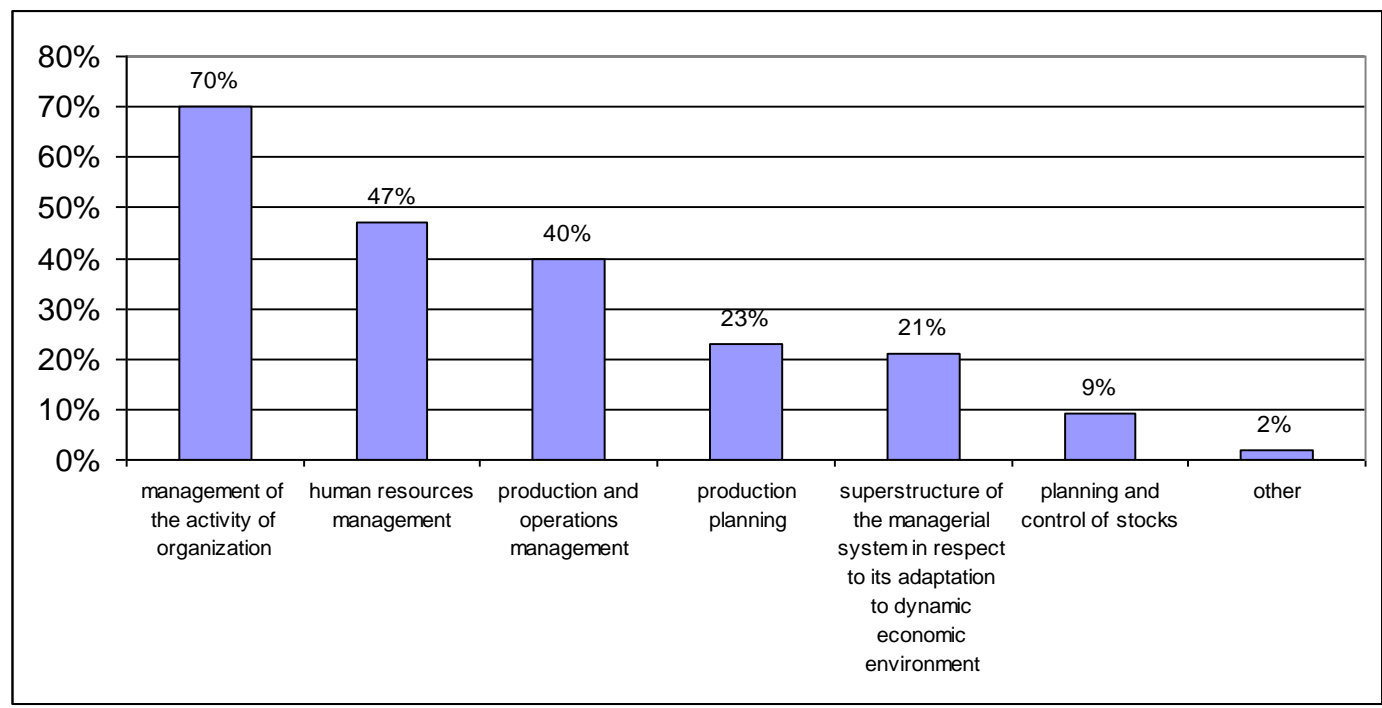

Fig. 6: Fundamental managerial tasks inherent for contemporary industrial managers (more than one answer is possible)

Lower is the support for production planning (23\%), superstructure of the managerial system in respect to its adaptation to dynamic economic environment (21\%) and planning and control of stocks (9\%) (Fig. 6).

Regarding key management functions, three groups are formed according to the results. The first one is the most consensus management function - control (supported by $75 \%$ of the interviewees). In the second group, having similar values, almost the half, are four management functions - leadership (60\%), planning $(53 \%)$, organizing (50\%) and coordinating $(46 \%)$. The third group is of not so popular as understanding - regulation and other management functions (2\% each) (Fig. 7). 


\author{
(online) $=$ ISSN $2285-3642$ \\ ISSN-L = 2285 - 3642 \\ Journal of Economic Development, Environment and People \\ Volume 3, Issue 2, 2014 \\ URL: http://jedep.spiruharet.ro \\ e-mail: office jedep@spiruharet.ro
}

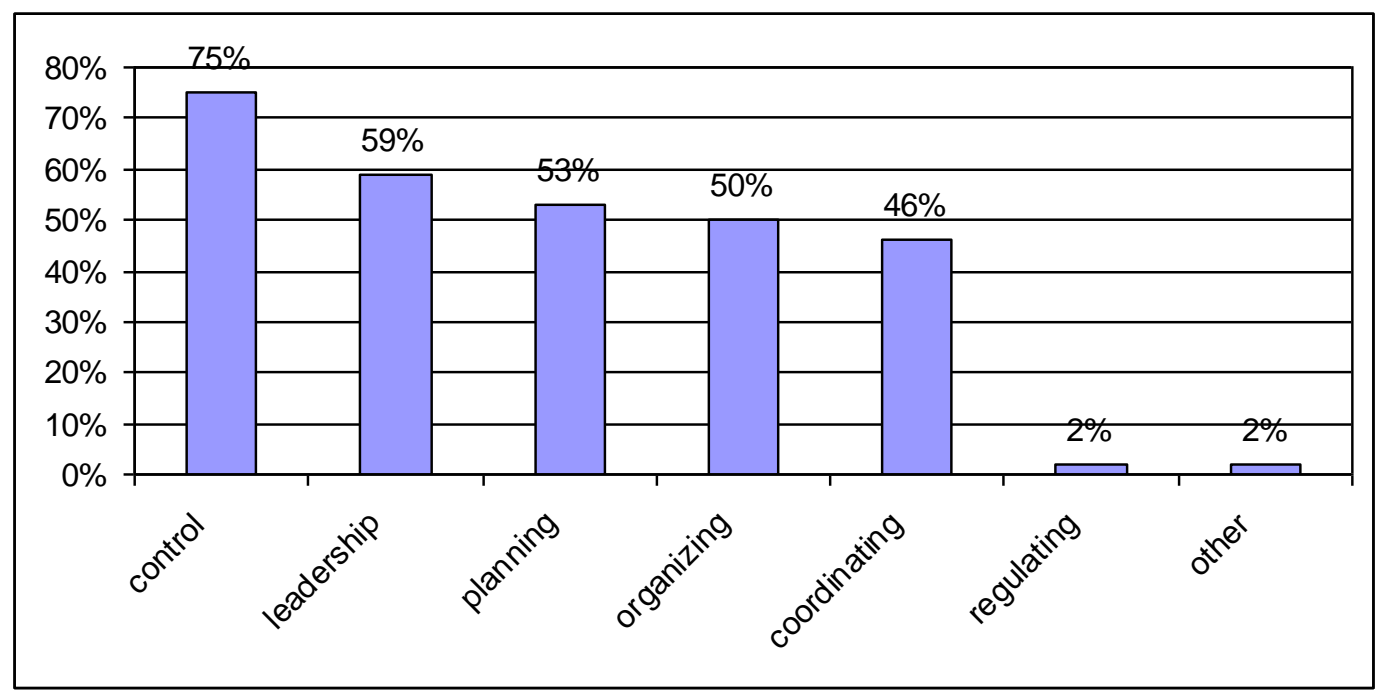

Fig. 7: Key management function for effective management process

(more than one answer is possible)

\title{
3.3.2. Results of the application of industrial management
}

According to the interviewees the best results in industrial management are achieved by managers (45\%) and technical specialists (43\%) (Fig.8). Representatives of extractive industry support that statements at the greatest extend ( $73 \%$ and $64 \%)$. In the rest of the groups such a consensus is not available. Behind the management staff is the organizations with linear-staff organizational structure (67\%). Increasing the age of the interviewees, increases the percentage of support: up to 30 years $-40 \%, 31-40$ years $-41 \%$, 51-60 years $-45 \%$, over $60-80 \%$. High managers (48\% of them) point mostly the management staff as the most successful in industrial management. Technical specialists have the best results according to $62 \%$ of the representatives of big companies having staff over 500 persons, for $80 \%$ of the interviewees from divisional structures, for $54 \%$ of higher education graduates (comparing to $13 \%$ of high education) and $56 \%$ of functional managers. Others with good results in industrial management are those having additional training in the field of management (for $36 \%$ of the interviewees), economists (27\%) and jurists (10\%) (Fig. 8). 


\author{
(online) $=$ ISSN $2285-3642$ \\ ISSN-L = 2285 - 3642 \\ Journal of Economic Development, Environment and People \\ Volume 3, Issue 2, 2014 \\ URL: http://jedep.spiruharet.ro \\ e-mail: office jedep@spiruharet.ro
}

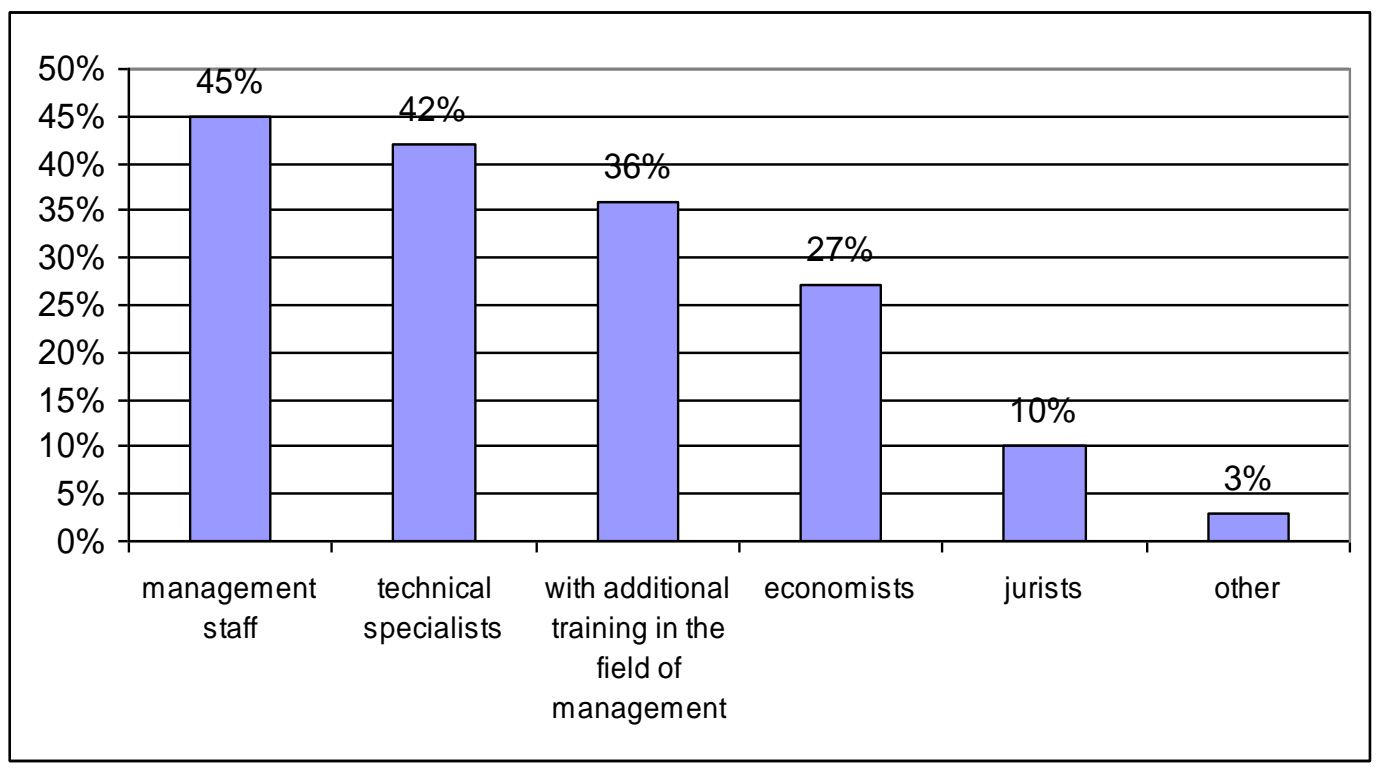

Fig. 8: "Who gains the best results in industrial management?"

(More than one answer is possible)

Those better results are achieved when managers stay for long periods in the organization passing consecutively through all hierarchical levels - that is the opinion of $74 \%$ of the interviewees (Fig. 9). The biggest percentage of adherents to that statement is among the representatives of extractive industry ( $91 \%$ of them) and processing industry (85\%), as well as representatives of big enterprises having staff over 500 persons ( $97 \%$ of them). The percentage of the supporters of that opinion is also high among representatives of divisional structure (87\%). $100 \%$ is the support of the respondents over 60 years old.

The second position, $47 \%$ support, is for the work with permanent team followed by frequent refresh of team in search for the best collaborators (9\%), alternation of periods of overload and those with little engagement (8\%) and frequent change of employer in search for new challenges (6\%) (Fig. 9). 


\author{
(online) $=$ ISSN $2285-3642$ \\ ISSN-L = 2285 - 3642 \\ Journal of Economic Development, Environment and People \\ Volume 3, Issue 2, 2014 \\ URL: http://jedep.spiruharet.ro \\ e-mail: office jedep@spiruharet.ro
}

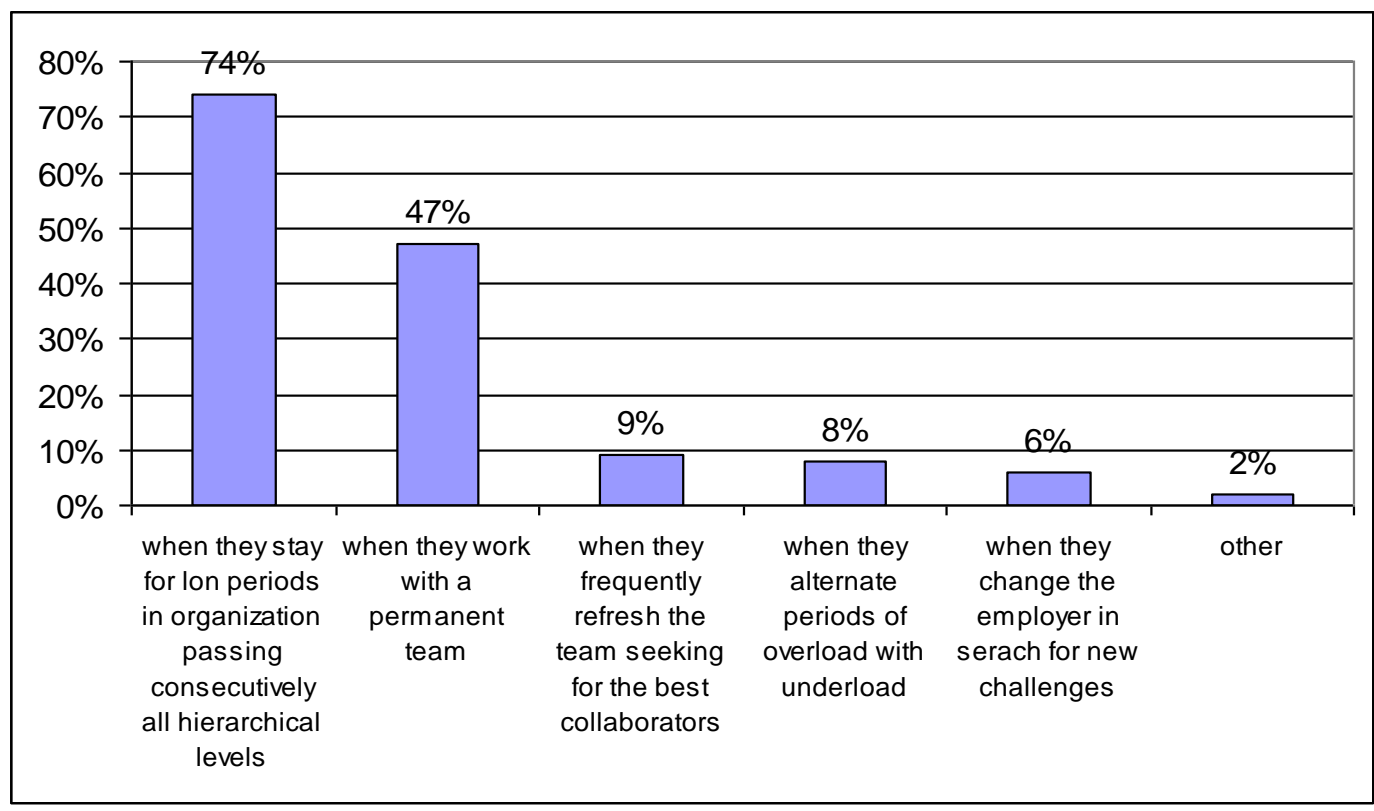

Fig. 9: Answers to the question "When managers achieve better results?"

(More than one answer is possible)

Very interesting is the support of higher education and high education graduates. Behind staying in the company and passing through all hierarchical levels are $82 \%$ of the interviewees with higher education and $53 \%$ of those with high education, while the work with permanent team is the reason for good results for $67 \%$ of high education graduates and $42 \%$ of higher education (Fig. 10).

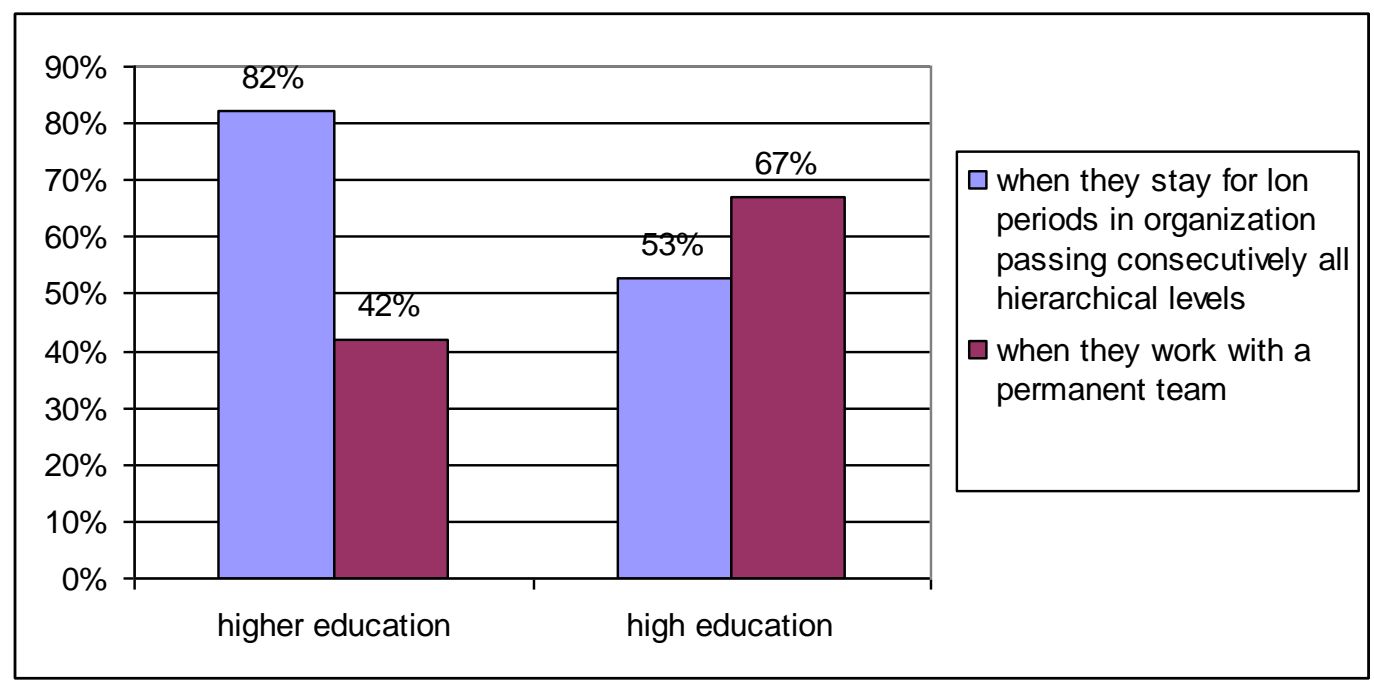

Fig. 10: Answers to the question "When managers achieve better results?" - distribution according to the education of the interviewees 


\author{
(online) $=$ ISSN $2285-3642$ \\ ISSN-L = 2285 - 3642 \\ Journal of Economic Development, Environment and People \\ Volume 3, Issue 2, 2014 \\ URL: http://jedep.spiruharet.ro \\ e-mail: office jedep@spiruharet.ro
}

The most important key parameter (Fig. 11) for the activity of $64 \%$ of the organizations is the economic effectiveness ${ }^{2}$. Most of its adherents are in extractive industry ( $81 \%$ of them), in companies having staff between 11 and 50 persons (77\%) and from 51 to 250 persons (75\%), as well as in the divisional structure (72\%). Almost $75 \%$ of functional managers point it and about $33 \%$ of the specialists. The second popular parameter is the quality of production, labor and management which is pointed by $54 \%$ of the interviewees (Fig. 11). The biggest is the support by big companies having over 500 persons staff (66\% of them point that) and representatives of divisional structures ( $87 \%$ of them). Increasing the age the percentage of supporting quality increases - up to 30 years old (47\%), 31 - 40 years (52\%), 41 - 50 years (61\%), 51 - 60 years (70\%). Over 60 years - none pointed it. The third place is for economic benefit (profit) which is marked by $40 \%$ of the interviewees. The most of its adherents are in trade, cars and motorbikes repair (65\%), among the representatives of linear-staff structure (83\%), among the interviewees with high education (53\%) and representatives of organizations property of a foreign investor (46\%). However, the choice of foreign investors is the financial stability which is a key issue for $66 \%$ of them. The financial stability is important for $25 \%, 23 \%$ point the expansion of production, $20 \%$ - revealing and realizing the full potential of organization. Only $3 \%$ mention the career development (Fig. 11).

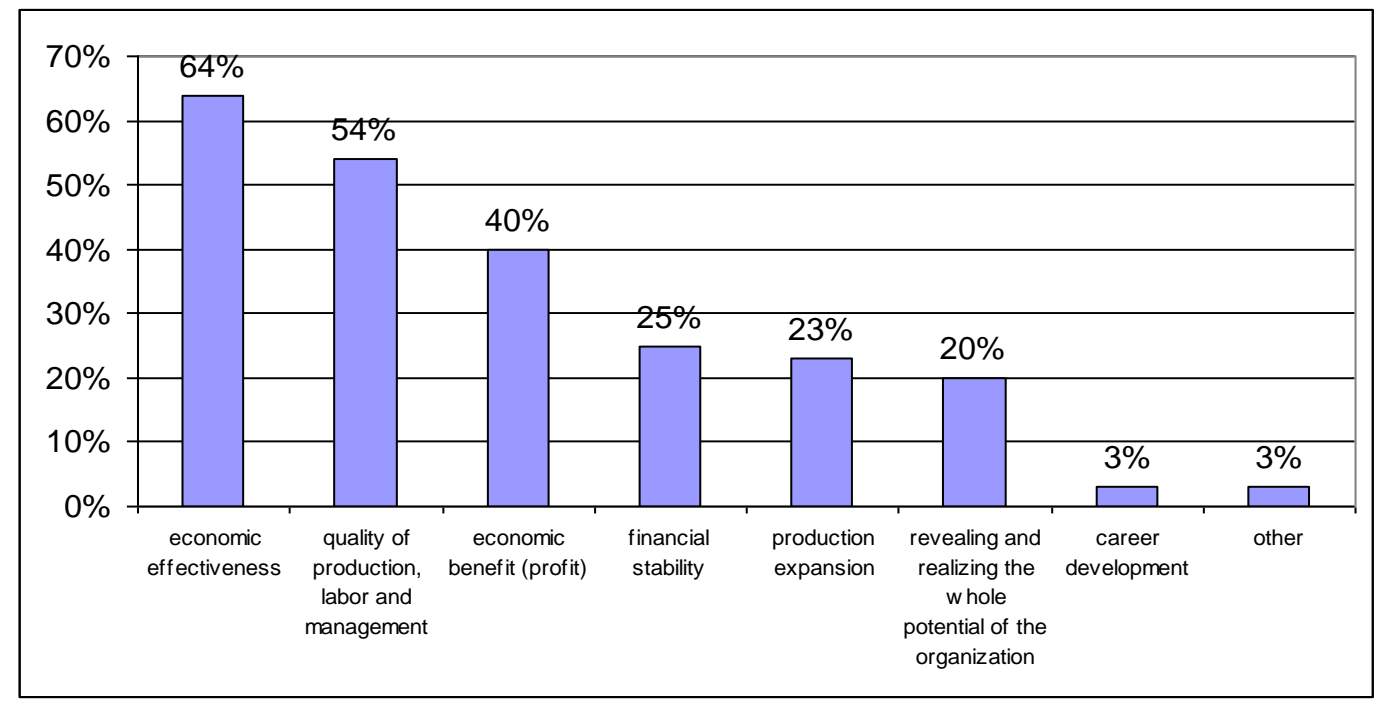

Fig. 11: "What of the pointed parameters are key for your organization's activities?" (More than one answer is possible)

\footnotetext{
${ }^{2}$ It should not be forbidden that "the care" of abiding key parameters of organizational management is on the first place care for that manager which wishes the organization to function normally, and "the therapy" is to become as possible less dependent on the changes in environment (macro and micro).
} 


\author{
(online) $=$ ISSN $2285-3642$ \\ ISSN-L = $2285-3642$ \\ Journal of Economic Development, Environment and People \\ Volume 3, Issue 2, 2014 \\ URL: http://jedep.spiruharet.ro \\ e-mail: office jedep@spiruharet.ro
}

The most specific characteristic of industrial management in the Republic of Bulgaria pointed by $38 \%$ of the respondents is that "the rules of industrial management are imposed by a regulator in the face of the state". The highest number of that statement is among the representatives of mixed enterprises (46\%), in big organizations with over 500 persons in staff $(59 \%)$ and $251-500$ (52\%), as well as among $60 \%$ of functional managers. Another peculiarity, pointed by $31 \%$, is that "it is put as a mechanism of functioning in organizations which reflects the phase of the life cycle of the national economy". Supporting that statement are $53 \%$ of the interviewees with high education and $27 \%$ of those with higher education. $26 \%$ of the interviewees support the statement that the industrial management in the country "differs from the traditional management because of the role and peculiarities of organizations as elements of industrial policy". Having $11 \%$ support are two special features: "increased informational asymmetry because of the lack of transparency of business (corporate secret) and insufficient corporate reconnaissance" and "it causes informational asymmetry between inner and outer investors". "Other" is pointed by $2 \%$.

The support for the statement of the use of active strategies for penetrating new markets is the biggest in all the groups and reaches $60 \%$ (Fig. 12). For $33 \%$ in order to avoid the risk of activities only in one geographical region is important as a prerequisite. Only $15 \%$ point "using redundant production capacity", for $14 \%$ is important to achieve savings from optimizing the quantities (Fig. 12).

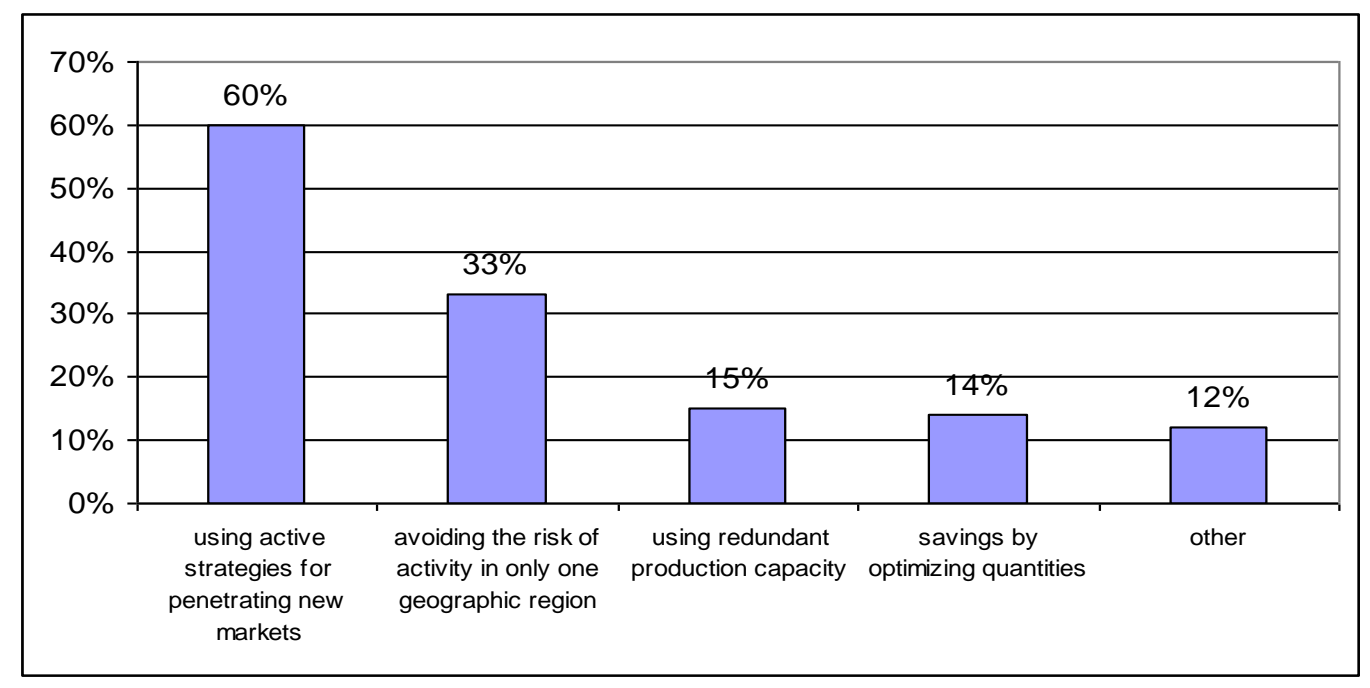

Fig. 12: Circumstances for internationalization of the organization's business (more than one answer is possible)

The determining factors of the level of productivity in conditions of globalization in business are two the quality of work and the level of techniques and technology. Both are pointed by $57 \%$ of the interviewees each: $73 \%$ of the representatives of extractive industry, $72 \%$ of those of production and distribution of electric and heat energy and gas fuels, while the quality of work is a priority for $77 \%$ of the 


\author{
(online) $=$ ISSN $2285-3642$ \\ ISSN-L = 2285 - 3642 \\ Journal of Economic Development, Environment and People \\ Volume 3, Issue 2, 2014 \\ URL: http://jedep.spiruharet.ro \\ e-mail: office jedep@spiruharet.ro
}

representatives of trade, cars and motorbikes repair. The quality of work is determining for $66 \%$ of Bulgarian companies, while for $69 \%$ of foreign companies the level of techniques and technology is important. Specialists (71\% of them) support the quality of work, while $72 \%$ of functional managers support the level of techniques and technology. Then the next factors come: the strategy of organization (for $40 \%$ of the interviewees) and the effectiveness of industrial management (21\%).

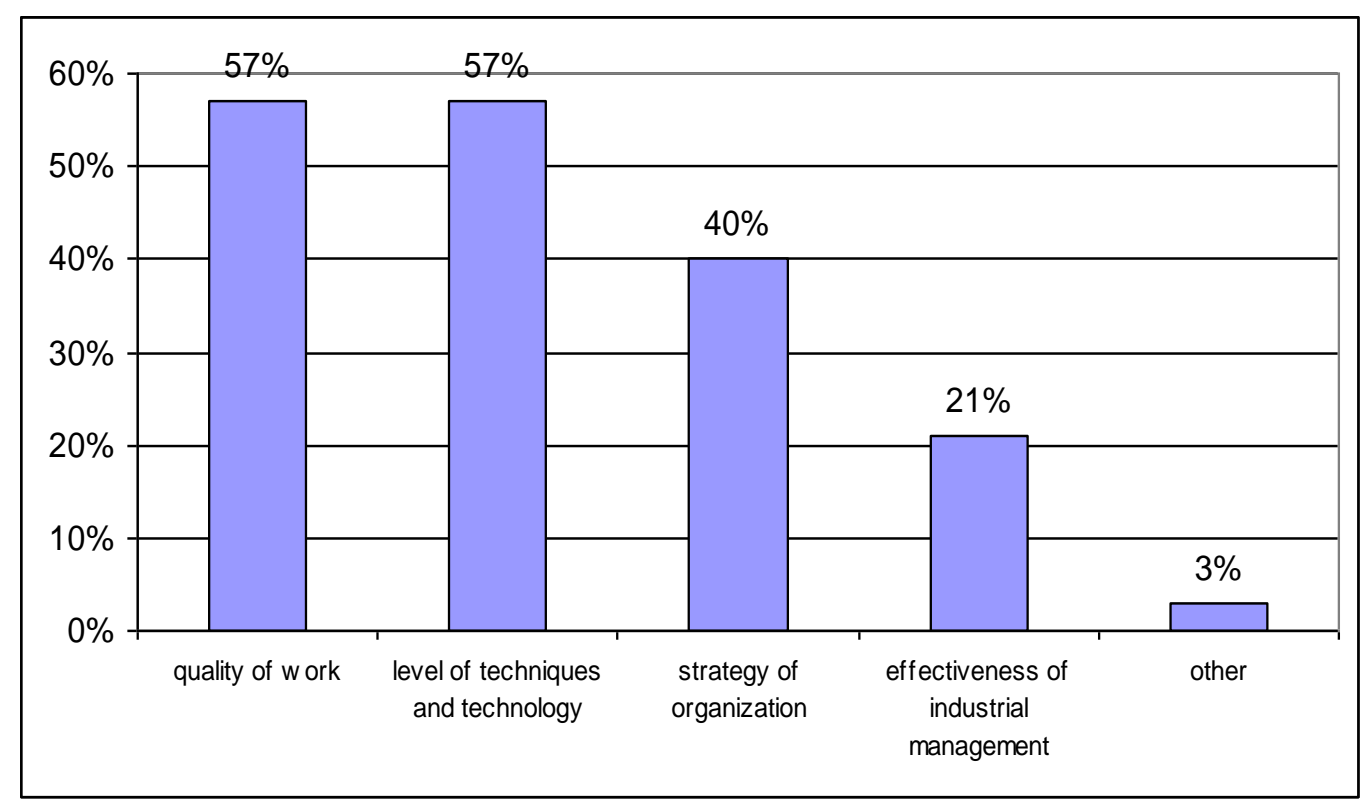

Fig. 13: Parameters determining the level of the productiveness in the organization in conditions of business globalization (more than one answer is possible)

For $42 \%$ of the interviewees a priority form for selling the ready product / service in XXI century will be the distributors - the representatives of processing industry (77\%) and functional managers (64\%) stand out. The second form is the promotion - for $35 \%$. That is the choice of $62 \%$ of representatives of foreign investors, $47 \%$ of the specialist and $67 \%$ of the interviewees up to 30 years old. "Other" is pointed by $23 \%$, $13 \%$ choose consignation, only $8 \%$ franchising (Fig. 14). 

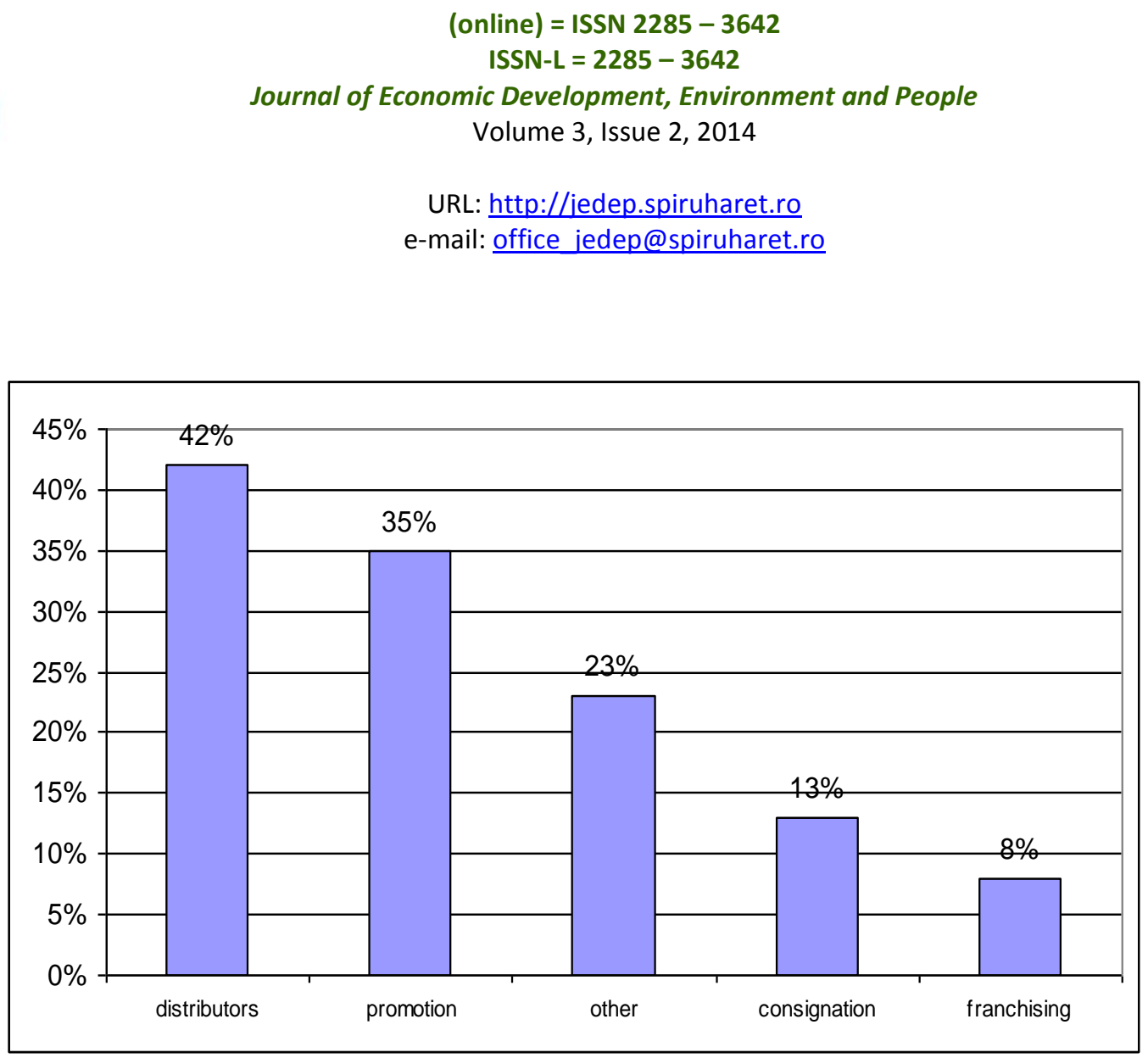

Fig. 14: Forms of realization of the ready product / service which would be of priority in XXI century (more than one answer is possible)

On the question about the necessity of creating NIMA the opinions are polarized (Fig. 15). The percentage of those which do not give any answer is not small (7.5\% of the interviewees). $52 \%$ are positive, $48 \%$ do not find that necessity. The most definite groups supporting NIMA are the representatives of the extractive industry (73\% of them), big companies with 500 persons $(78 \%)$ and $251-500$ persons $(72 \%)$, divisional structure (86\%) and functional managers (78\%).

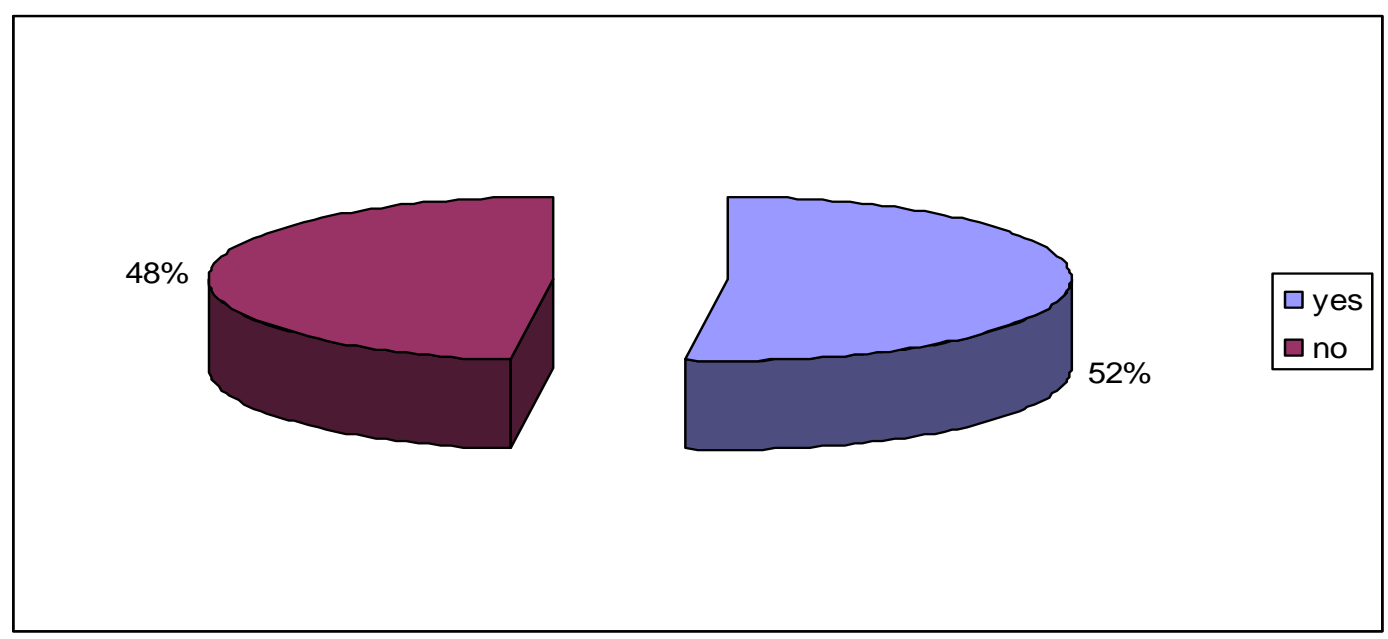

Fig. 15: "Is it necessary the establishment of NIMA in order organizations to answer adequately to the challenges of XXI century" 


\author{
(online) = ISSN $2285-3642$ \\ ISSN-L = 2285 - 3642 \\ Journal of Economic Development, Environment and People \\ Volume 3, Issue 2, 2014 \\ URL: http://jedep.spiruharet.ro \\ e-mail: office jedep@spiruharet.ro
}

The percentage of the opponents of NIMA is the highest among the representatives of trade, cars and motorbikes repair (56\% of them), small enterprises having staff from 11 to 50 persons (76\%) and up to 10 persons (75\%), functional and organizational-managerial structure (62\%) and specialists (65\%).

On the question of the basic components of NIMA only those answered positively for NIMA give feedback. For $67 \%$ of them the strategy is the basic one. The second place is for globalization (markets, technological development, innovations, products, etc.). With support by under the half of the interviewees are the principles (49\%) and the policy (22\%) (Fig. 16).

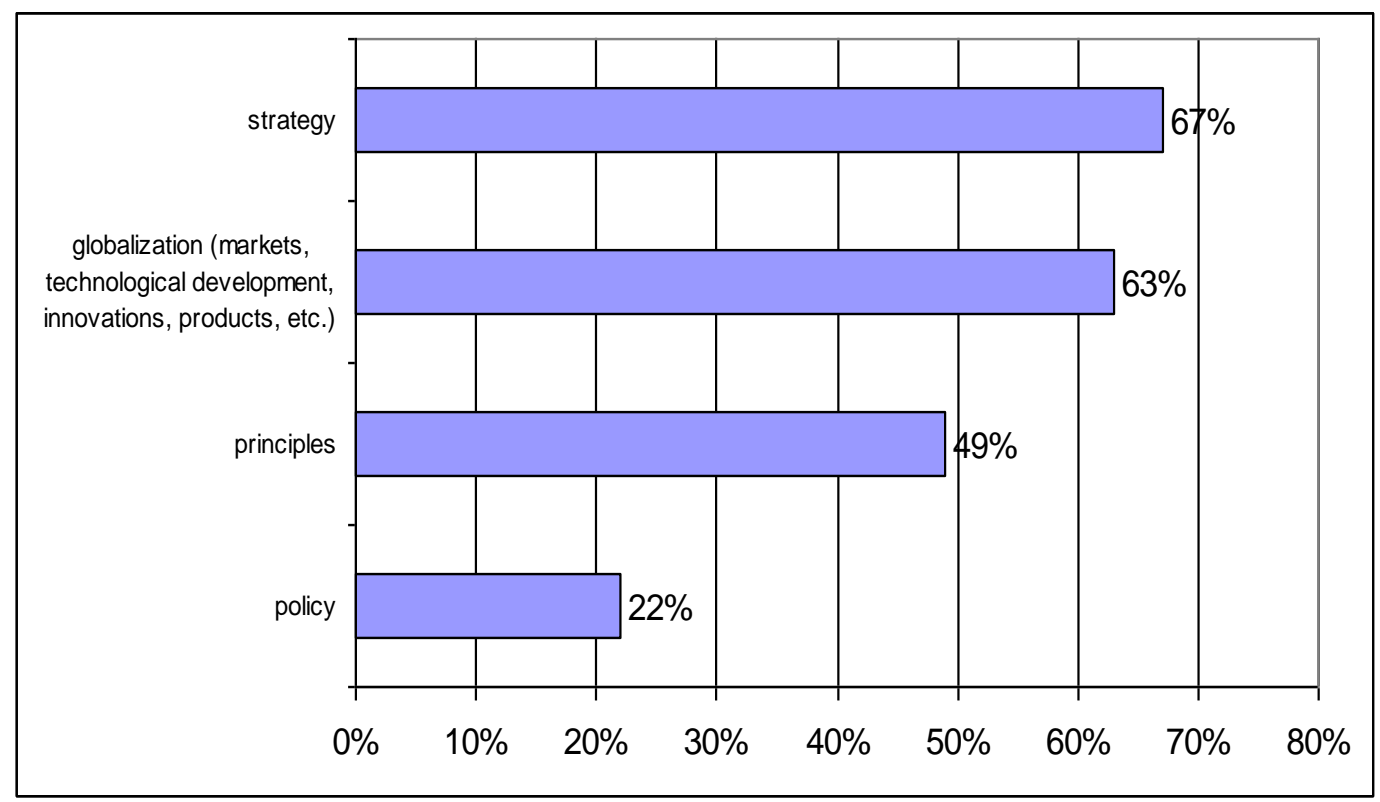

Fig. 16: Basic components of NIMA (more than one answer is possible)

\title{
3.3.3. Positioning main priorities of industrial management
}

For the most of adherents of NIMA the basic priority is the competitive policy ${ }^{3}$ in conditions of liberalization and globalization (57\%) (Fig. 17). Other competitive policy are "the regulatory function of state oriented towards final results" (41\%) and "new corporate culture" (39\%). "Social responsibility and ethics of organization" (28\%) and "the regulative role of state differentiated in respect to advantages and disadvantages" (18\%) have lower support. "Other" is pointed by $6 \%$. "Association of industrial capital" is basic for NIMA according to only $2 \%$ of the interviewees.

\footnotetext{
${ }^{3}$ Competition is dependent on the growth in productiveness. On corporate level productiveness is determined by the strategy of the organization, management and the quality of work. In other words, competitiveness is linked directly to the economic freedom. And in disagreement of what is competitiveness, there is a consensus on what it is not. And it is not: abundance of natural resources, cheap labor, special subsidies and preferential conditions for society.
} 


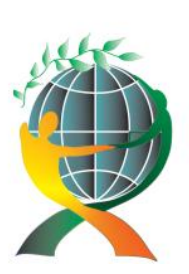

\author{
(online) $=$ ISSN $2285-3642$ \\ ISSN-L = 2285 - 3642 \\ Journal of Economic Development, Environment and People \\ Volume 3, Issue 2, 2014
}

URL: http://jedep.spiruharet.ro

e-mail: office jedep@spiruharet.ro

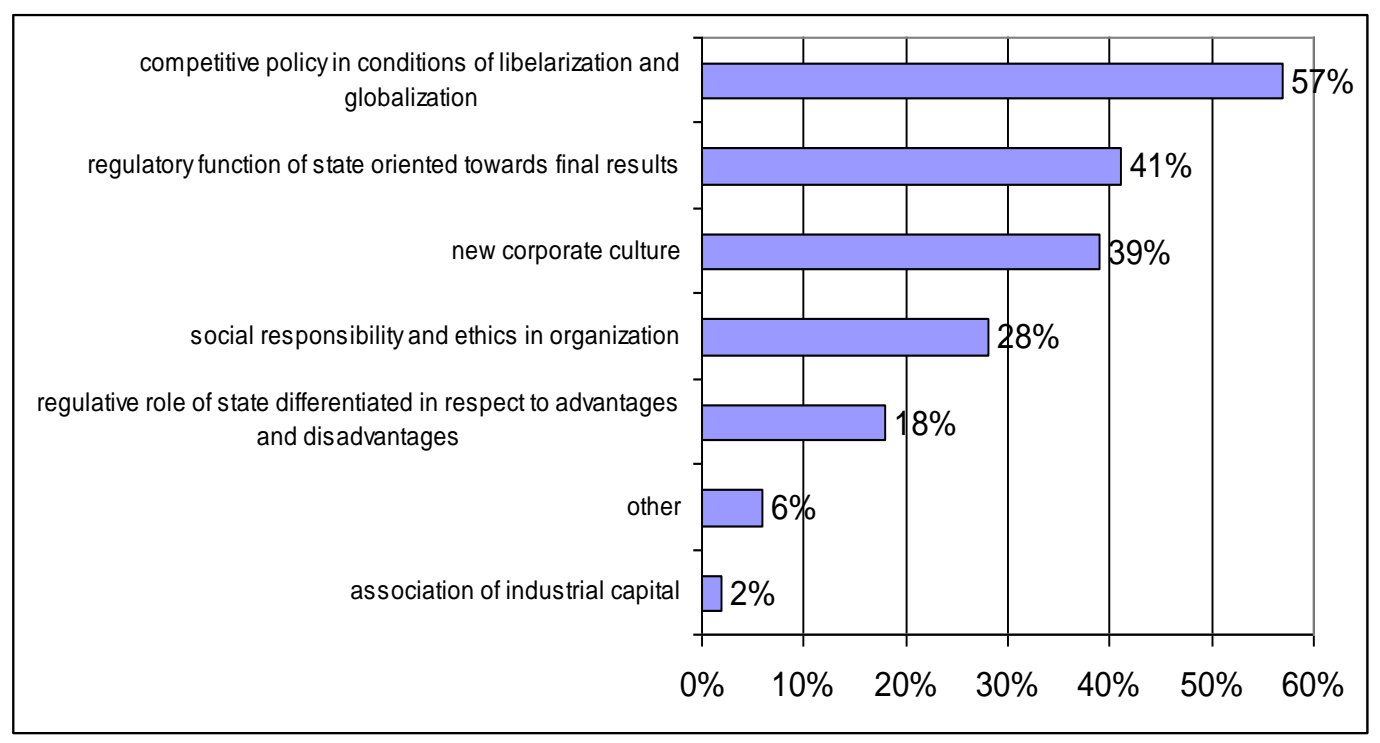

Fig. 17. Structure defining parameters for NIMA - distribution among the adherents of NIMA

The data show a high level of consensus on formulated challenges before industrial management in XXI century. Among the answers the partial or full disagreement varies between $11 \%$ and $15 \%$. In that sense the agreement is between $85 \%$ and $89 \%$. The biggest challenge before industrial management in XXI century according to the interviewees is "the management in the global environment" ${ }^{4}$. 52\% point "completely agree", 38\% - "agree", 10\% - "disagree", among which only $1 \%$ are categorical in their opinion (Fig. 18). "Social responsibility and ethics of organization" and "new corporate culture" have similar percentages ( $88 \%$ each in the "agree" points). $12 \%$ in each do not agree. The opponents of the first statement are bigger percentage (8\%) than the second $(2 \%) .49 \%$ support the challenge of "entrepreneurship". It has the highest percentage of disagreement - $14 \%$. Only $25 \%$ are fully convinced that "Career management" is a challenge before the industrial management, and only $2 \%$ state the opposite (Fig. 18).

\footnotetext{
${ }^{4}$ In new global environment in the scope of industrial management, industrial managers respectively, the fields that are most critical should be concerned. For the country under investigation those are: the real sector (especially small enterprises and selfemployed), households with debts and peripheral municipalities. That means that they are touched in the greatest extend by the crisis in the economics (and not only the budget) and the labor markets and incomes.
} 


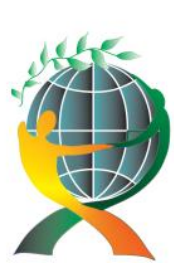

\author{
(online) $=$ ISSN $2285-3642$ \\ ISSN-L = 2285 - 3642 \\ Journal of Economic Development, Environment and People \\ Volume 3, Issue 2, 2014
}

URL: http://jedep.spiruharet.ro

e-mail: office jedep@spiruharet.ro

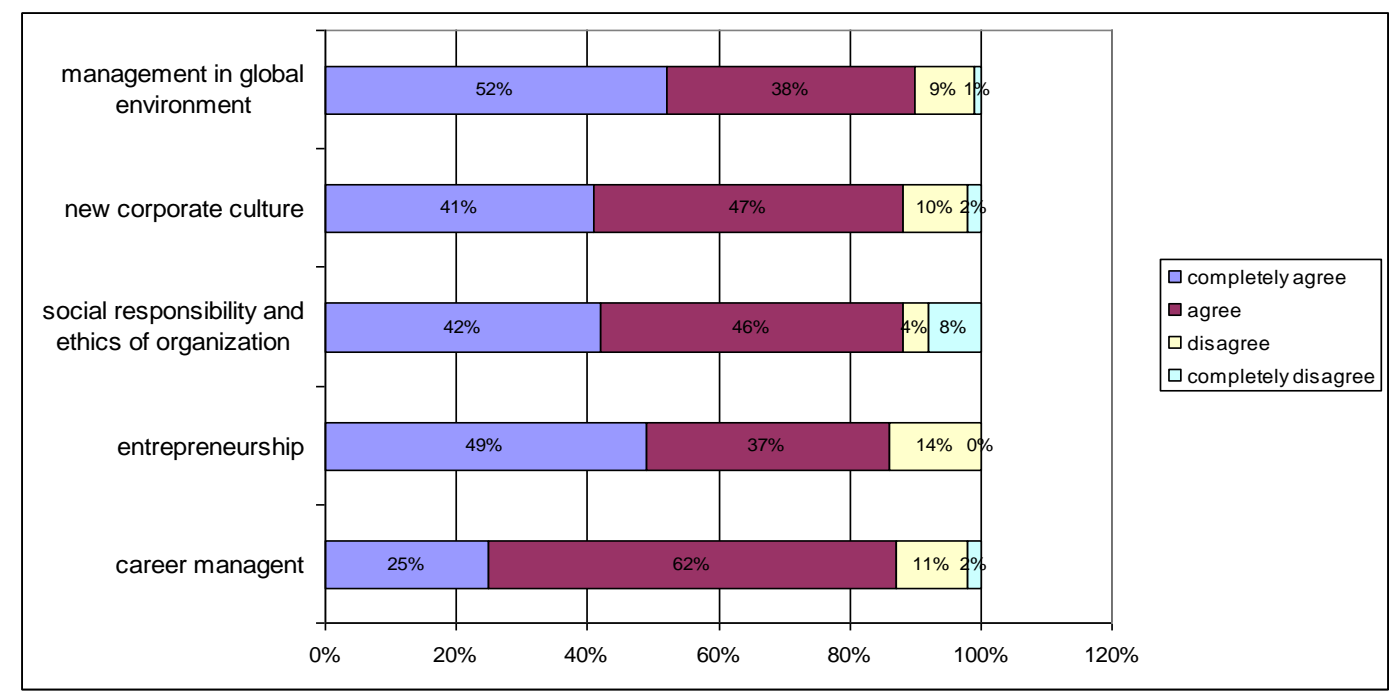

Fig. 18: Main challenges before industrial management in XXI century

The most anticipated problem in the process of functioning of the organizations in XXI century is "strengthening competition" (Fig. 19). Only $13 \%$ do not agree with that opinion, while only $4 \%$ of them are categorical. "The raise in the prices of resources" is a consensus problem - $86 \%$ with partial or full agreement. Among other expected obstacles, supported by over the half of the interviewed specialists, are "bank credits" and "globalization of business (73\% each), as well as "unfair competition" (56\%). There is embarrassment for "introduction of new forms of branch and international cooperation" (60\% of the respondents). "The shortening of the life cycle of the products" is not a problem for $59 \%$, the biggest percentage here is for those categorical in their opinion (31\% state that it is completely non-applicable for their organizations). Looking ate "the corruption environment" and "difficulties in covering the costs for scientific, research and transfer activities in the period of commercialization" the optimists prevail and 59\% (in both cases) do not expect those as forthcoming problems. 


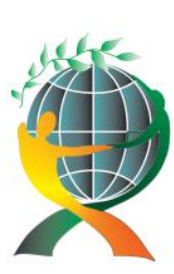

\author{
(online) $=$ ISSN $2285-3642$ \\ ISSN-L = 2285 - 3642 \\ Journal of Economic Development, Environment and People \\ Volume 3, Issue 2, 2014
}

URL: http://jedep.spiruharet.ro

e-mail: office jedep@spiruharet.ro

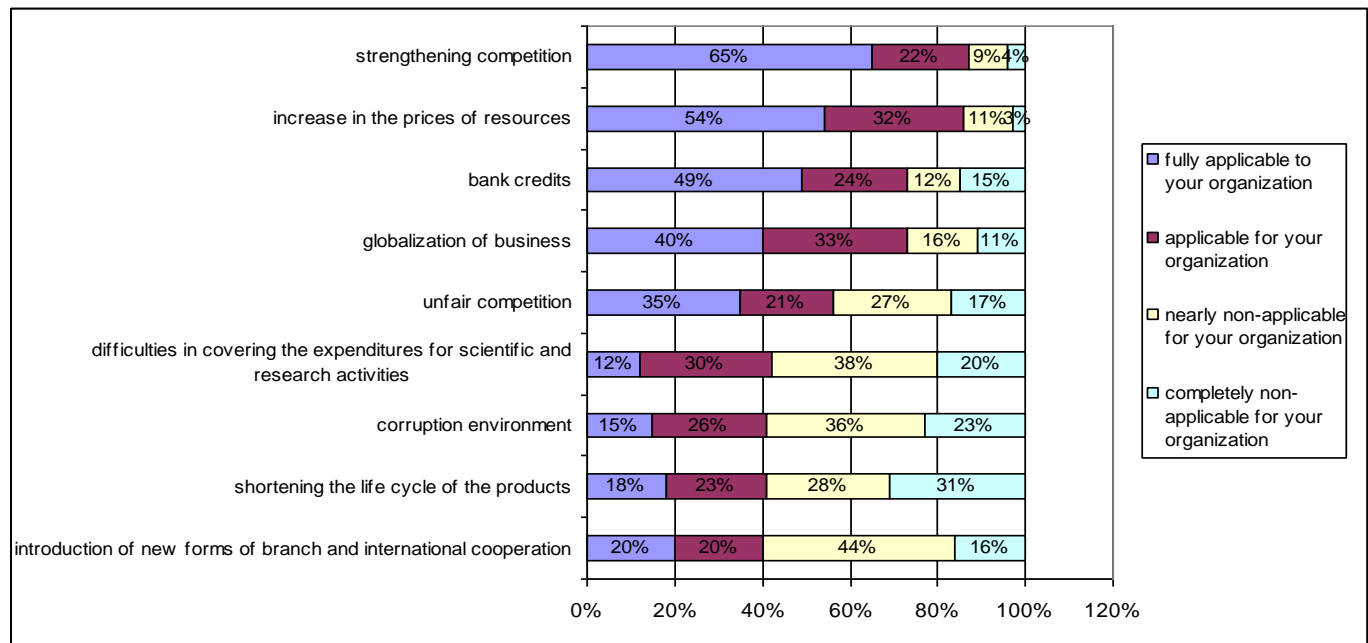

Fig. 19: Expected problems before industrial management in XXI century in respect to the effectiveness of organizations' functioning

\title{
3.3.4. Instruments for determining effectiveness of industrial management in organizations
}

There is no a universal technique in determining the effectiveness of industrial management in organizations. The polarization in opinions is mainly in two directions: "analysis of the economic effectiveness of organization" (54\%) and "analysis of the financial profitableness" of the organization (50\%) (Fig. 20). For $21 \%$ of the respondents "the analysis of the growth of the organization" is litmus of success. Only $4 \%$ point that they do not use techniques in determining the effectiveness of their own organization.

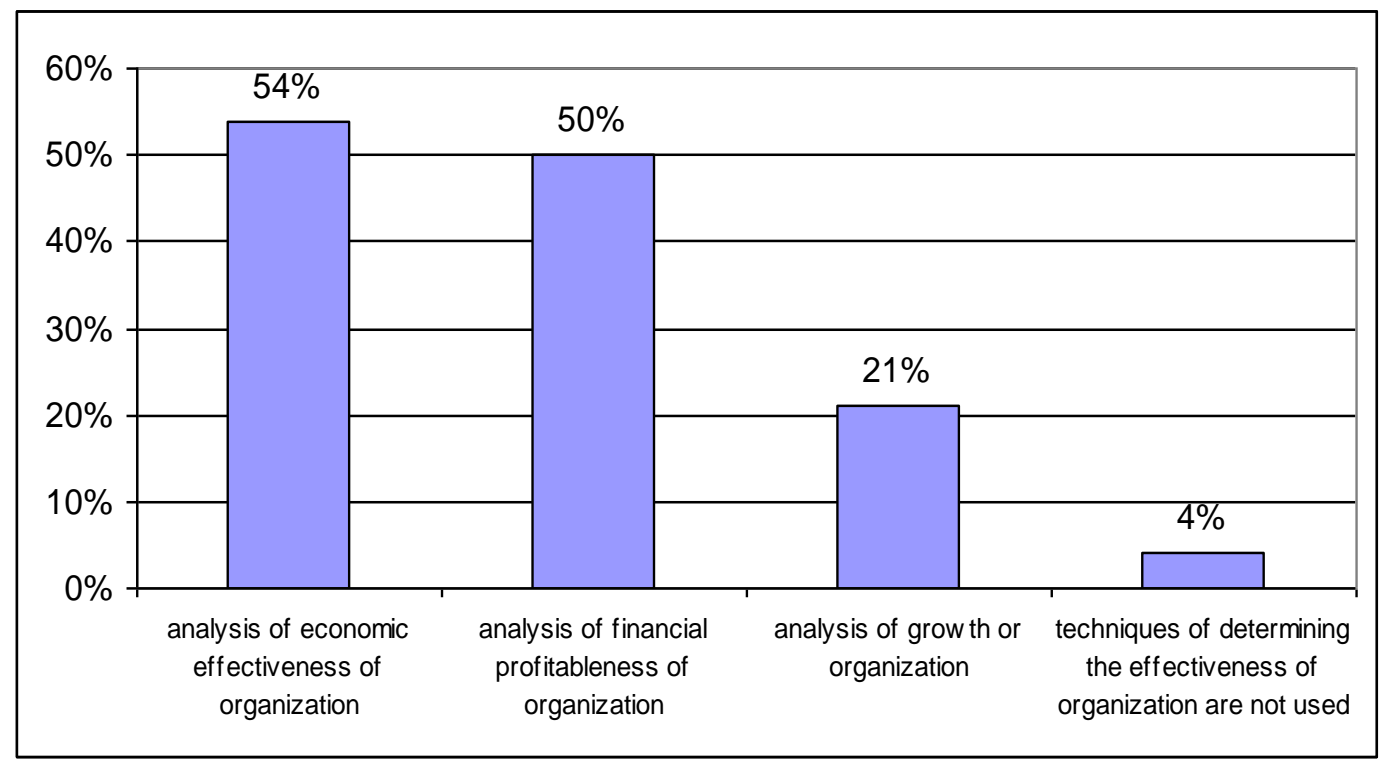

Fig. 20: Used techniques in determining the effectiveness of industrial management (more than one answer is possible) 


\author{
(online) = ISSN $2285-3642$ \\ ISSN-L = 2285-3642 \\ Journal of Economic Development, Environment and People \\ Volume 3, Issue 2, 2014 \\ URL: $\underline{\text { http://jedep.spiruharet.ro }}$ \\ e-mail: office jedep@spiruharet.ro
}

\title{
4. Conclusions
}

Summarizing the results of the investigation, the following conclusions can be formulated:

1. For almost two of every three organizations the classical approach towards the industrial management is determining.

2. For contemporary industrial managers the most peculiar task is the management of the activity and the organization which could be achieved in the greatest extend by control. That could mean that namely in the control implementation the biggest difficulties could hide, on one hand, and on the other - it is underestimated at the current moment. Key parameters for the organizational activities are economic effectiveness and quality of production, labor and management.

3. Managers achieve better results when stay for longer periods in organizations passing consecutively hierarchical levels (the outstanding workers in industrial management are usually the management staff and technical specialists). Another positive feature is the work with a permanent team. Only for one of every ten managers high results are achieved in change of organization in searching for new challenges when alternating periods of overload and less engagement and frequent change of the team seeking the best collaborators. The success is available in development of professional career in the frames of one organization and with permanent team. The change of work and team are counter-indicative for most of the interviewed managers.

4. The peculiarities of the industrial management in the Republic of Bulgaria are connected to the rules which are imposed by a regulator in the face of the state. The specificity is the fact that the industrial management is put as a mechanism of functioning of organizations reflecting the phase of life cycle of the national economy. The increased informational asymmetry because of the lack of transparency in business or between inner and outer investors is not pointed as a peculiarity of industrial management because it collects only $1 / 10$ of the answers of the interviewees.

5. The quality of work and the level of techniques and technology determine the level of productivity. Distribution and presentation have future in marketing of products and services. On the backstage are the consignation and franchising. The internationalization of business is possible when using active strategies for penetrating new markets.

6. The expert opinion is divided in respect to the necessity of the establishment of a new form of international management architecture (NIMA). For its adherents the basic are strategy and globalization (markets, technological development, innovations, products, etc.). The structure defining for that form is the competitive policy in conditions of liberalization and globalization. Other significant parameters are the regulative function of state orientated towards final results, and the new corporate culture.

7. The big challenge before the industrial management in XXI century is the management in contemporary global environment. In the foreground are the corporate social responsibility and ethics and new corporate culture in organizations. The expected problems in the process of functioning of organizations in XXI century is the strengthening in competition and raise in the prices of resources. Others are bank credits and globalization of business, as well as unfair competition. 


\author{
(online) $=$ ISSN $2285-3642$ \\ ISSN-L = $2285-3642$ \\ Journal of Economic Development, Environment and People \\ Volume 3, Issue 2, 2014 \\ URL: http://jedep.spiruharet.ro \\ e-mail: office jedep@spiruharet.ro
}

8. Regarding the techniques of determining the effectiveness of industrial management polarization in given opinions is noticed. It is mainly in two directions - analysis of economic effectiveness and of financial profitableness of organizations.

In conclusion, it can be stated that the confidence in the usefulness of the current research is supported by the contradictory processes of differentiation and integration. The character of both in the scientific knowledge of management predetermines the necessity of development of appropriate methodological concept of industrial management which to integrate the results of that empirical investigation, different analyses, statements and conclusions formulated in other scientific fields concerning the main business priorities of the Republic of Bulgaria in XXI century. Today, the following topics are closely connected to the industrial management: entrepreneurship, knowledge-based economy, network economy, industrial management in the new global environment, career management, corporate social responsibility and ethics and new corporate culture. All that is predetermined by the fact that the effective industrial manager analyzes the problems of management and then he/she solves them applying appropriate management theories.

\title{
5. References
}

[1] Otavio Jose de Oliveira, Guidelines for the integration of certifiable management systems in industrial companies, Journal of Cleaner Production, Volume 57, 15 October 2013, Pages 124-133

[2] Antonella Meneghetti, Gioacchino Nardin, Enabling industrial symbiosis by a facilities management optimization approach, Journal of Cleaner Production, Volume 35, November 2012, Pages 263-273

[3] Linda D. Peters, Andrew D. Pressey, Markus Vanharanta, Wesley J. Johnston, Theoretical developments in industrial marketing management: Multidisciplinary perspectives, Industrial Marketing Management, Volume 42, Issue 3, April 2013, Pages 275-282 